\title{
Penggalian Seni Tradisi Tari Telek di Banjar Kangin Desa Adat Panjer Denpasar Selatan
}

\author{
Ni Made Liza Anggara Dewi ${ }^{1}$, Ni Made Haryati²
}

1. Program Studi Pendidikan Seni Pertunjukan, Fakultas Seni Pertunjukan, Institut Seni Indonesia Denpasar, Jln Nusa Indah, Denpasar, 80235, Indonesia

2. Penelitian Dosen Pemula, Institut Seni Indonesia Denpasar, Jln Nusa Indah, Denpasar, 80235, Indonesia

nimadelizaanggaradewi@gmail.com

Tari Telek di Banjar Kangin Desa Adat Panjer memiliki kekhasan dari segi sejarah awal mula terciptanya tari Telek tersebut, bentuk, dan fungsinya memiliki kekhasan tersendiri. Perlu untuk dilakukan penelitian secara mendalam dengan tujuan penggalian seni tradisi langka yang ada di Kota Denpasar. Penelitian ini menggunakan pendekatan Sosio Historis dengan metode analisis deskriptif kualitatif. Data diperoleh melalui sumber langsung berupa wawancara terstruktur, dan secara tidak langsung melalui studi kepustakaan dan dokumentasi. Adapun hasil yang didapatkan yaitu tari Telek yang merupakan bagian dari pementasan sesolahan Sesuhunan atau manifestasi Tuhan Yang Maha Esa tersebut masih dilestarikan hingga sekarang. Tari Telek yang ada di Banjar Kangin Desa Adat Panjer merupakan bagian dari pertunjukan Tari Barong, Rangda, Rarung, dan Topeng Sidakarya yang berfungsi sebagai sarana pengungkapan kepercayaan atau keyakinan dari masyarakat penyangganya yaitu khususnya masyarakat Banjar Kangin terhadap keberadaan manifestasi Tuhan yang berstana sebagai Sesuhunan berupa Barong, Rangda, Rarung, dan Topeng Sidakarya yang menjaga dan melindungi masyarakat Desa Adat Panjer Denpasar Selatan.

Kata kunci: panjer, seni tradisi, telek

Telek dance in Banjar Kangin, Panjer Traditional Village, is unique in terms of the history of the origin of the Telek dance, its form, and function, so it is necessary to conduct in-depth research with the aim of extracting rare traditional arts in Denpasar City. This study uses a Socio History approach with Qualitative Descriptive Analysis method. Data obtained through direct sources in the form of interviews and indirectly through literature and documentation studies. The results obtained are the Telek dance which is part of the sesuhanan sesolahan performance which is still preserved until now. The Telek dance in the Banjar Kangin traditional village of Panjer is part of the performance of the Barong, Rangda, Rarung, and Sidakarya Masks which function as a means of expressing the beliefs or beliefs of the supporting community, namely the Banjar Kangin community towards the existence of God's manifestations who are seated as sesuhunan in the form of Barong, Rangda, Rarung, and Sidakarya masks in the traditional village of Panjer, the traditional village of Panjer.

Key words: panjer, traditional art, telek

Proses review: 1 - 15 September 2021, Dinyatakan lolos 17 September 2021 


\section{PENDAHULUAN}

Berkesenian adalah gerakan yang dilakukan untuk mengungkapkan pengalaman batin seseorang untuk mendapat tanggapan dari orang lain (Murgiyanto, 1986:23). Seni sebagai satu dari unsur kebudayaan, memiliki ciri dan hakikat yang sangat bergantung dari respon dan lingkungan masyarakat di mana seni tari itu berasal. Tari Bali yang merupakan hasil olah rasa, cipta dan karsa dari masyarakat dan senimannya, sangat diikat oleh nilai-nilai budaya Hindu Bali. Sejalan dengan perkembangannya berjalan searah dengan perkembangan masyarakatnya. Di Bali, seni tari menjadi bagian dalam kehidupan masyarakatnya yang diwarisi sejak zaman dahulu hingga saat ini. Gerakan yang lincah dan dinamis yang selaras dengan gamelan sebagai musik pengiringnya menjadi ciri khas dari tari Bali. Sesuai dengan konteks perkembangan budaya, tari Bali dapat diklasifikasikan menjadi 2 yaitu: tari tradisional dan tari non tradisonal. Tari tradisional merupakan taritarian yang dipelihara oleh suatu masyarakat secara turun temurun. Sehingga dapat dikatakan tari-tarian ini telah memiliki perjalanan yang cukup panjang dan memiliki pola dan pembendaharaan gerak yang sudah baku. Tari non tradisional merupakan tari kreasi baru yang berkembang diluar kaidah yang mengikat dan tidak adanya batasan bagi senimannya. Perkembangan budaya Bali mengikutiarus kehidupan sosial, ekonomi dan teknologi pada masyarakat Bali. Sejalan dengan hal tersebut penetrasi nilainilai baru dari modernisasi telah banyak mengubah cara berpikir, cara hidup, dan selera masyarakat pendukungnya. Akibatnya eksistensi generasi penerus dan identitas budaya tradisonal Bali semakin lama semakin terancam. Maka perlu adanya upaya dalam penggalian seni tradisi khususnya seni pertunjukan tari. Karena seni pertunjukan tari akan habis atau hilang setelah dipentaskan, sehingga perlu upaya masyarakat penyangganya untuk tetap memberikan ruang bagi keberadaan seni pertunjukan tari agar tidak terlupakan. Beda halnya dengan seni rupa yang memiliki wujud menetap dan masih dapat dinikmati oleh generasi berikutnya. Dilihat dari perkembangannya, semakin sulit untuk mengingat kembali semua jenis tari yang ada, maka dikhawatirkan akan terjadi jenis tari yang pernah dijaga dan diperlihara hilang dari ingatan atau terlupakan ketika tarian tersebut sudah jarang dipentaskan. Mengakibatkan hampir selalu sesuatu yang didapatkan oleh generasi penerus semata-mata hanya sebagai informasi sisa. Bahkan tarian yang pernah ada atau sudah tua dikemudian hari digarap kembali oleh generasinya menjadi sebuah dugaan bahwa tari yang hidup sekarang berbeda dengan tari yang hidup beberapa generasi sebelumnya. Oleh karena itu, melalui penggalian seni tradisi ini diharapkan dapat menambah refrensi berupa dokumen dan ikut serta menjaga seni tradisi khususnya seni pertunjukan tari agar tidak terlindas oleh arus globalisasi.

Salah satu contoh tari tradisional yang ada di Bali yaitu Tari Telek, Tari Barong, dan Tari Topeng Bang yang merupakan khasanah budaya yang sampai sekarang ini menjadi junjungan masyarakat Bali yang adi luhung. Dibia dalam bukunya Selayang Pandang Seni Pertunjukan Bali mengatakan bahwa semula Tari Topeng Bang atau Jauk menjadi satu dalam pertunjukan Barong Ket yang dikenal dengan sebutan Telek. Di dalam perkembangannya kemudian semua tarian tersebut memisahkan diri menjadi tarian tersendiri (1999:32). Tari Telek, Barong, dan Topeng Bang diyakini secara niskala diciptakan oleh para dewa dari khayangan yang disebut Sang Hyang Trisemaya yaitu Dewa Wisnu, Dewa Brahma, dan Dewa Iswara. Keberadaan tarian ini tersirat kuat dalam teks lontar Barong Swari. Sehingga melalui hasil interpretasi dan imajinasinya para seniman terdahulu mentransformasikan nilai-nilai teks lontar Barong Swari ke dalam seni pertunjukan seperti Tari Telek, Tari Topeng Bang, dan Tari Barong (Cerita, 2020: 109-114). Sebagai kesenian yang sudah mengalami perjalanan yang sangat panjang pertunjukan tari Telek ini masih tetap dilestarikan dan berkembang sampai saat ini di berbagai daerah di Bali. Seperti tari Telek yang dipakemkan oleh ASTI Denpasar, Tari Telek Desa Jumpai Klungkung, Tari Telek Desa Adat Legian Badung, Tari Telek Desa Munggu Badung, Tari Telek Pemogan Denpasar, Tari Telek Sidakarya Denpasar, dan Tari Telek Panjer Denpasar. Masing-masing daerah memiliki berbagai ciri khas yang mencerminkan kearifan lokal setempat dimana tarian itu berkembang dengan keunikannya tersendiri, yaitu: terdapat berbagai macam bentuk, gaya atau style, hingga dalam konteks pertunjukan yang berbeda-beda sesuai dengan pakem dan nilai yang dianut masyarakat daerah penyangganya. Tari Telek yang dikenal dengan ciri khasnya menggunakan topeng berwarna putih dan berkarakter halus, membawa kipas sebagai properti, dan menggunakan kostum awiran merupakan salah satu jenis tari sakral sebagai pengiring suatu upacara keagamaan di Bali. Penciptaan Tari Telek dipercaya bersumber dari 
Lontar Barong Swari yaitu: yang berhubungan erat dengan kepercayaan Agama Hindu terhadap mitologi Hindu Bali yang mengisahkan kerinduan Bhatara Siwa kepada Bhatari Giri Putri atau Dewi Uma yang menjelma ke dunia menjadi Dewi Durga. Bandem dalam bukunya Ensiklopedi Tari Bali mengatakan juga bahwa Tari Telek dipercaya bersumber dari Kitab Adi Parwa yang mengambil lakon Pemutaran gunung Mandara Giri atau Ksirarnawa yang mengisahkan para dewa dan raksasa yang berusaha menarik pengikat gunung yaitu Naga Basuki untuk mencari Tirtha Amertha (1983:139-140). Seperti cerita yang tersirat dalam teks Lontar Barong Swari dan Kitab Adi Parwa tersebut, Tari Telek yang ada di Banjar Kangin Desa Adat Panjer Denpasar Selatan juga memiliki hubungan yang sangat erat dengan kedua sumber tersebut sehingga menjadi bagian dalam pementasan Tari Barong, Rangda, Rarung yang merupakan simbol manifestasi Tuhan masyarakat Banjar Kangin Desa Adat Panjer Denpasar Selatan.

Tari Telek yang merupakan warisan budaya tradisional masyarakat Banjar Kangin Desa Adat Panjer Denpasar Selatan memiliki bentuk pertunjukan tari dengan struktur dan ragam gerak yang khas sebagai tari pengiring sesolahan atau pementasan dari Sesuhunan atau manifestasi Tuhan masyarakat Desa Panjer yaitu berupa Barong, Rangda, Rarung, dan Topeng Sidakarya. Secara visual pementasan tari Telek ini berbeda dari bentuk pertunjukan tari Telek pada umumnya yang berdiri sendiri sebagai tari Telek. Ngurah Krisna selaku koordinator dan pembina pertunjukan Tari Telek di Banjar Kangin Desa Adat Panjer Denpasar Selatan mengatakan, bahwa Tari Telek tersebut merupakan sebuah seni pertunjukan yang dipelihara secara turun temurun oleh Banjar Kangin Desa Adat Panjer Denpasar Selatan (hasil wawancara pada hari jumat, 5 Maret 2021). Dikatakan juga bahwa tari Telek tersebut adalah tarian sakral yang merupakan warisan leluhur dan pantang jika tidak dipentaskan. Karena pertunjukan ini diyakini sebagai sarana untuk memohon keselamatan khususnya bagi Banjar Kangin Desa Adat Panjer Denpasar Selatan. Bahkan demi menjaga warisan leluhur seluruh pakem pada pementasan Tari Telek tetap dipertahankan sebagaimana adanya. Pementasan Tari Telek ini merupakan sebuah rentetan dari pertunjukan manifestasi dari Bhatara dan Bhatari yang dipuja yaitu berupa Barong, Rangda, Rarung dan Topeng Sidakarya yang dilaksanakan setelah sasih kasanga atau bulan dalam perhitungan Bali pada bulan sembilan hingga sasih kapitu atau bulan ke tujuh, karena sasih kapitu dipercayai sebagai sasih atau bulan yang rawan, karena secara logika pada sasih kapitu adalah musim hujan jadi Sesuhunan bersemayam di Pura. Semua penari yang mengikuti pementasan tersebut pertamanya harus melalui upacara penyucian diri atau disebut mawinten yang disertai upacara mejaya-jaya yang dilakukan setiap 6 bulan sekali. Pementasan Tari Telek ini biasanya ditarikan pada Upacara Dewa Yadnya di Khayangan Tiga Desa Adat Panjer Denpasar Selatan, di Pura Dalem Tanjung Sari Desa Adat Tanjung Bungkak Denpasar dan Pura Tegal Penangsaran Desa Adat Panjer. Selain terkait dengan upacara adat, pementasan tari Telek dapat dilakukan setiap bulan purnama dan tilem sebagai waktu khusus untuk pementasan dari permohonan masyarakat yang memiliki hutang janji dalam kepercayaannya atau biasa disebut mesesangi.

Berdasarkan uraian di atas, penulis sangat tertarik untuk melakukan sebuah penggalian terhadap seni tradisi khususnya Tari Telek yang ada di Banjar Kangin Desa Adat Panjer Denpasar Selatan. Beberapa hal yang perlu untuk dikaji antara lain: awal mula keberadaan tari, bentuk pertunjukan tari, dan fungsi pertunjukan tari Telek di Banjar Kangin Desa Adat Panjer Denpasar Selatan. Adapun halhal yang mendorong keinginan untuk meneliti Tari Telek di Banjar Kangin Desa Adat Panjer Denpasar Selatan adalah sebagai berikut: Pertama mengingat Tari Telek tersebut memiliki bentuk pertunjukan yang khas dan belum ada yang meneliti baik itu awal mula, bentuk dan fungsi dari Tari Telek di Banjar Kangin Desa Adat Panjer Denpasar Selatan tersebut. Kedua, untuk mengetahui lebih dalam mengenai kondisi yang ada, hubungan antara Tari Telek sebagai warisan budaya, kepercayaan yang diyakini oleh masyarakat penyangganya, dan masyarakatnya itu sendiri. Meskipun berada di pusat kota dengan perkembangan cara hidup yang pesat, masyarakat Banjar Kangin Desa Adat Panjer masih tetap melestarikan Tari Telek sebagai warisan budaya dengan rasa pengabdian yang tulus. Ketiga, untuk menambah refrensi kajian tertulis mengenai seni tradisi sebagai pengetahuan bagi masyarakat luas, dan sebagai acuan tertulis dikemudian hari bagi generasi penerus masyarakat Banjar Kangin, khususnya mengenai Tari Telek Khas Banjar Kangin Desa Adat Panjer Denpasar Selatan. 


\section{METODE PENELITIAN}

Penelitian ini menggunakan pendekatan kualitatif yang merupakan payungnya semua jenis pendekatan yang digunakan untuk meneliti kehidupan sosial natural atau alamiah (Sugiyono, 2019: 361). Lokasi penelitian dilakukan di Banjar Kangin Desa Adat Panjer Denpasar Selatan yang merupakan tempat dimana Tari Telek tersebut dilestarikan oleh masyarakatnya. Masyarakat di desa tersebut mulai dari Penua atau Penglingsir Desa Adat, pelaku seni atau seniman, Pemangku di Pura Dalem Desa Adat Panjer, Pembina dan koordinator pertunjukan, penari dan penabuh tari Telek yang merupakan sumber informasi dalam mengumpulkan data penelitian terhadap awal mula keberadaan, bentuk dan fungsi pertunjukan tari terkait dengan penggalian seni tradisonal Tari Telek di Banjar Kangin Desa Adat Panjer Denpasar Selatan. Subjek penelitian ini adalah masyarakat dari Banjar Kangin Desa Adat Panjer Denpasar Selatan, khususnya yaitu: Lurah, Kelihan Banjar, penglingsir atau penua sebagai tokoh adat dan seni budaya, pemangku, pembina, penari dan penabuh. Objek penelitian ini adalah Tari Telek yang ada di Banjar Kangin Desa Adat Panjer Denpasar Seletan. Pelaksanaan pengumpulan data dilakukan melalui metoda observasi, wawancara, studi kepustakaan, dan studi dokumentasi. Teknik pengumpulan data dilakukan melalui teknik wawancara terstruktur kemudian data yang dikumpulkan diklasifikasikan sebagai berikut: 1) Data mengenai awal mula dari keberadaan Tari Telek di Banjar Kangin Desa Adat Panjer Denpasar Selatan. 2) Data mengenai Bentuk Tari Telek di Banjar Kangin Desa Adat Panjer Denpasar Selatan. 3) Data mengenai fungsi dari Tari Telek di Banjar Kangin, Desa Adat Panjer Denpasar Selatan.

\section{HASIL DAN PEMBAHASAN}

\section{Awal Mula Keberadaan Tari Telek Di Banjar Kangin Desa Adat Panjer Denpasar Selatan}

Tari adalah salah satu pernyataan budaya. Oleh karena itu maka sifat, gaya, dan fungsi tari selalu tak dapat dilepaskan dari kebudayaan yang menghasilkannya (Edi Sedyawati, 1986:3). Tari Telek yang ada di Banjar Kangin Desa Adat Panjer merupakan rangkaian dari pertunjukan sesolahan Sesuhunan di Desa Adat Panjer berupa Barong, Rangda, Rarung, dan Topeng Sidakarya. Barong dan Rangda merupakan urat akar Budaya Bali, yang bersumber dari Tatwa Kanda Empat Buta yaitu dapat dilihat dari kebiasaan masyarakat Bali dengan cara tersendiri dalam menyampaikan ucapan rasa syukur dan terima kasih kepada sifat Tuhan yang berbeda-beda. Pementasan Tari Barong dan Rangda bertujuan untuk menceritakan sifat Tuhan yang memiliki unsur dualistik atau di Bali lebih dikenal dengan Rhwa Bhineda, dan juga dapat dikatakan berperan sebagai ayah dan ibu yang menciptakan kehidupan ini (Budihartini, 1999:13-14) Awal mula dari keberadaan Sesuhunan dan tari Telek tersebut tidak diketahui angka tahunnya, karena menurut aparat desa dan masyarakat setempat semuanya merupakan warisan terdahulu yang memang sudah didapatkan oleh kakek nenek mereka seperti itu tanpa ada bukti peninggalan yang pasti. Pertunjukan tari Telek dan Jauk dalam pertunjukan tersebut merupakan rententan yang tidak bisa terpisahkan dari pertunjukan Tari Barong, Rangda, Rarung dan Topeng Sidakarya sebagai Sesuhunan di Banjar Kangin Desa Adat Panjer Denpasar Selatan tersebut. Topeng merupakan benda penutup mukayang berasal dari kata tup yang berarti tutup (Bandem,1983: 140). Topeng yang digunakan pada Sesuhunan Barong, Rarung, Topeng Sidakarya, Telek dan Jauk tersebut kecuali topeng Rangda dapat dikatakan barang purbakala, karena angka tahun pembuatannya sudah sampai tidak diketahui oleh siapa pun. Bahan kayu dari topeng Barong didapatkan dari Pura Khayangan Dalem Tanjung Sari Desa Adat Tanjung Bungkak. Sehingga setiap odalan atau upacara di Pura Dalem tersebut, tepatnya pada rahinan anggara kasih medangsia, sepuluh hari setelahnya Sesuhunan Banjar Kangin melakukan pementasan di sana. Akan tetapi Bahan kayu topeng dari Sesuhunan Rarung, Topeng Sidakarya, Telek dan Jauk tidak diketahui asal usulnya.

Informasi yang diketahui mengenai tari Telek yaitu daritahun1958yangmerupakanawalmulaSesuhunan di Banjar Kangin baru dibangkitkan kembali setelah pandemi cacar air yang mewabah dari tahun 1953 sampai 1958 tersebut. Sesuai tradisi di Desa Panjer pada waktu tertentu yaitu satu tahun sekali sebelum sasih kesanga menuju sugihan Bali, Sesuhunan disimpan untuk sementara dan mulai dibangkitkan setelah sasih kesanga dan boleh dipentaskan sampai sasih kapitu karena setelah sasih kapitu menuju sasih kasanga dipercaya merupakan waktu yang rawan dan secara logika merupakan musim hujan jadi Sesuhunan disimpan di gedong penyimpanan dan tidak boleh dipentaskan. Pada tahun 1953 di Desa Panjer terjadi gerubug gering agung atau pandemi 
cacar air yang memang sangat mewabah. Penduduk Banjar Kangin setiap harinya kurang lebih sampai tiga orang yang meninggal karena wabah cacar air tersebut. Karena wabah penyakit yang begitu besar dan kondisi yang begitu mencekam dari penyakit mematikan tersebut, sehingga warga dari Desa Panjer tidak sempat mengadakan upacara untuk membangunkan atau membangkitkan Sesuhunan dari penyimpanan. Suatu ketika ada pemangku yang bertugas, mengalami kerasukan yang dipercaya dari Sesuhunan menyatakan bahwa; jika Sesuhunan tidak dibangunkan dari penyimpanan, semua penduduk akan habis karena wabah penyakit ini. Pada saat itu seluruh masyarakat Banjar Kangin menyanggupi untuk mengadakan upacara pembangkitan kembali atau membangunkan Sesuhunan yang sudah lama tersimpan. Sesuhunan tersebut merupakan simbol manifestasi Tuhan dari Desa Adat Panjer yang berstana di Pura Khayangan Dalem. Karena situasi pandemi yang begitu mewabah sehingga perekonomian masyarakat Desa Adat Panjer pun terpuruk. Ketika itu beberapa dari masyarakat Desa Adat Panjer membuat perkumpulan sekha Barong untuk penggalian dana, dengan berusaha bekerja ke sawah menjadi sekha manyi. Usaha mengumpulkan dana tersebut dilakukan untuk dapat mengadakan upacara pembangkitan kembali atau membangunkan Sesuhunan yang telah lama tersimpan. Sekha Barong atau sekha manyi tersebut didominasi oleh masyarakat Banjar Kangin dan diantaranya ada beberapa orang dari Banjar Antap, Banjar Sasih, Banjar Kaja, Banjar Celuk Desa Adat Panjer, bahkan ada beberapa warga dari Desa Adat Sesetan yang mempunyai hubungan keluarga dari Desa Adat Panjer yang turut membantu menjadi sekha manyi. Mereka menjadi buruh pertanian keluar desa hingga keluar kabupaten untuk mengumpulkan dana. Tempat atau lokasi dimana mereka bekerja akan ditandai dengan kober poleng atau bendera berwarna hitam, putih, dan abu yang besar dan panjang sebagai tanda sekha Barong dari Desa Adat Panjer Denpasar Selatan yang bekerja sebagai sekha manyi di sawah. Perjalanan panjang dan melelahkan dalam keadaan sulit menjadi buruh pertanian dirasa begitu berat, sehingga beberapa warga pelan-pelan menghilang dan tidak ikut serta lagi membantu untuk mengumpulkan dana, kecuali masyarakat dari Banjar Kangin dengan keyakinannya terhadap Sesuhunan begitu besar dan kuat tetap berusaha untuk mengumpulkan dana sampai akhir. Sehingga danapun terkumpul untuk mengadakan upacara pembangkitan kembali dari hasil menjadi sekha manyi, yang ketika itu hanya dilakukan oleh masyarakat Banjar Kangin. Pengempon Sesuhunan atau yang berkewajiban dan berwenang terhadap Sesuhunan dari awal pembangkitan hingga sekarang adalah masyarakat Banjar Kangin, yaitu: menjaga dan merawat, mengadakan upacara, hingga melestarikan tradisi sesolahan atau pertunjukan tari dari Sesuhunan berupa Tari Barong, Tari Rangda, Tari Rarung, Tari Topeng Sidakarya, Tari Telek dan Tari Jauk yang menjadi satu kesatuan pertunjukan yang utuh. Semua hal yang berkaitan dengan Sesuhunan tersebut merupakan tanggung jawab dari masyarakat Banjar Kangin walapun Sesuhunan tersebut milik Desa Adat Panjer yang berstana di Pura Khayangan Dalem Desa Adat Panjer. Hingga sekarang setiap kurang lebih 10 tahun sekali, masyarakat Banjar Kangin mengadakan pembaharuan terhadap wujud fisik dari Sesuhunan tersebut. Pembaharuan yang dilakukan, seperti: mengganti warnanya atau memberikan polasan cat yang baru, memperbaiki bagian yang rusak, dan khusus untuk Barong, Rangda dan Rarung rambut atau bulu-bulunya diganti dengan yang baru. Bahan dari kulit sebagai hiasan pun diganti agar Sesuhunan terlihat seperti baru lahir kembali walaupun kayu yang menjadi bahan utama dari topeng sebagai perumpamaan wajah tersebut tidak pernah diganti dari sejak dulu, yang tidak diketahui kapan angka tahun pembuatannya. Setelah diadakan pembaruan wujud fisik tersebut, barulah diadakan Upacara Ngayum yaitu sebuah rangkaian upacara besar yang dilakukan dengan penuh rasa pengabdian dan syukur, bertujuan untuk mengembalikan kekuatan atau dapat dikatakan mengembalikan nyawanya kembali sebagai manifestasi Bhatara dan Bhatari yang menjaga dan melindungi masyarakat, khususnya masyarakat Banjar Kangin Desa Adat Panjer Denpasar Selatan.

Sesuhunan yang ada di Desa Adat Panjer tersebut juga memiliki nama tersendiri atau sebutan khusus oleh masyarakat terhadapNYA, yaitu: Sesuhunan berupa Barong disebut Ratu Ayu Tanjung Sari, Sesuhunan berupa Rangda disebut Tumas Jegeg Nyanggelan, Sesuhunan berupa Rarung disebut Ratu Bang, dan Sesuhunan berupa Topeng Sidakarya disebut Ratu Topeng. Topeng dari Sesuhunan Rangda sudah pernah diganti sebanyak tiga kali. Diketahui pertama yaitu tahun 1958, awal mula Sesuhunan dibangkitkan kembali dari penyimpanan setelah pandemi cacar air. Bahan kayu dari topengnya didapatkan dari nunas atau meminta kayu di Pura Tegal Penangsaran Desa Adat Panjer, sehingga 
setiap piodalan atau upacara di Pura tersebut, Sesolahan Sesuhunan dengan Tari Telek dan Jauk di dalamnya dipentaskan dengan kaitan upacara yang dilakukan. Kemudian ketika berumur 12 tahun kayu dari topeng Rangda tersebut kembali mengalami perapuhan, yaitu pada tahun 1971 kembali diganti. Bahan kayu dari topengnya didapatkan dari nunas atau meminta kayu di Pura Dalem Tanjung Sari Desa Adat Tanjung Bungkak dimana tempat nunas kayu dari topeng Barong. Kemudian setelah berumur 11 tahun, kayunya kembali mengalami perapuhan dan disimpan dengan bingkai di dinding Gedong yaitu tempat penyimpanan Sesuhunan tersebut. Pergantian topeng Sesuhunan Rangda yang ketiga yaitu pada tahun 1982 dengan nunas kayu di Banjar Kaja Desa Adat Panjer yang bertahan keawetannya hingga sekarang dan sudah berumur 39 tahun. Namun topeng dari Sesuhunan Barong, Rarung, Topeng Sidakarya, dan Telek tidak diketahui angka tahun pembuatannyanya. Topeng tersebut hingga saat ini masih utuh dan belum pernah terganti. Hanya saja dipolas untuk perubahan warna, yaitu awalnya dulu masih menggunakan warna alami dari tulang, akan tetapi sekarang sudah menggunakan cat kimia dengan warna yang cerah. Ratu Topeng atau Sesuhunan Topeng Sidakarya pernah terdengar informasi yang tidak tau kepastiannya, bahwa kayunya tersebut berasal dari kayu Pohon Pule di daerah Banjar Nyanggelan. Cerita yang tersebar, yaitu disuatu hari ada orang yang sedang bermain layang-layang, layangan tersebut merupakan layangan janggan besar dengan menggunakan topeng wirmana. Ketika itu seperti ada pawisik untuk menjadikannya bahan dari perwujudan Sesuhunan di Desa Adat Panjer, sehingga katanya sisa topeng layangan tersebutlah digunakan sebagai topeng dari Sesuhunan Ratu Topeng. Topeng Telek dan Jauk memang sudah ada sejak dulu tanpa ada informasi yang diketahui, walau ada beberapa dari topeng Jauk yang sudah ada diganti.

Bukti peninggalan purbakala berupa topeng dari Sesuhunan tersebut, yang diketahui sudah ada sejak dulu dan sudah berstana di Pura Khayangan Dalem Desa Adat Panjer Denpasar Selatan. Awal mula keberadaan dan angka tahun pembuatan pasti dari topeng tersebut, dapat dikatakan tidak diketahui oleh 8 generasi sebelumnya. Sehingga awal mula keberadaan Tari Telek yang ada di Banjar Kangin Desa Adat Panjer Denpasar Selatan, dilihat dari peninggalan topeng yang digunakan, juga tidak diketahui tahun yang pasti awal mula keberadaannya.
Informasi sisa dari masyarakat penyangganya hanya diketahui awal mula pembangkitan kembali dari pandemi cacar air pada tahun 1985 karena keyakinan masyarakat Banjar Kangin terhadap keberadaanNya. Keyakinan masyarakat yang sangat kuat akan keberadaan Sesuhunan yang menjaga dan melindungi mereka tersebut, diyakini nyata adanya. Kekuatan dari Sesuhunan yang dipercaya oleh masyarakat Banjar Kangin, yaitu seperti banyak permohonan dan doa dari masyarakat yang terpenuhi olehNya. Ketika ada orang sakit yang katanya sudah tidak dapat diobati, baik itu orang yang sakit ataupun keluarga dari yang sakit memohon, berdoa dan berjanji kepada Sesuhunan yang berstana di Pura Khayangan Dalem Desa Adat Panjer: jika bisa sembuh akan menghaturkan upacara sesolahan atau pertunjukan tari dari Sesuhunan tersebut, dan sangat diyakini pasti sembuh oleh masyarakat Banjar Kangin. Karena begitu kuat kepercayaan dan keyakinan masyarakat Banjar Kangin akan keberadaan dan kekuatan sesuhunan melindungi masyakaratnya, sehingga pertunjukan tari Telek yang merupakan bagian dari pementasan sesolahan Sesuhunan tersebut masih dilestarikan hingga sekarang.

\section{Bentuk Tari Telek Di Banjar Kangin Desa Adat Panjer Denpasar Selatan}

Bentuk adalah esensi dari berbagai unsur menjadi satu bagian dalam kesatuan yang utuh. Dalam mengkaji sebuah seni dapat digali melalui persoalan bentuk (Form), fungsi, maupun makna (Content) (Kuta Ratna, 2010: 345). Seperti halnya dalam ilmu pengetahuan seni tari, bentuk tari dapat dilihat dari berbagai aspek, yaitu bentuk tari berdasarkan perkembangan dan keberadaannya, berdasarkan tata cara penyajiannya, dan berdasarkan bentuk koreografinya. Tari Telek yang ada di Banjar Kangin Desa Adat Panjer Denpasar Selatan, dilihat dari perkembangan dan keberadaannya saat ini termasuk dalam bentuk tari tradisional. Tari Telek yang ada di Banjar Kangin Desa Adat Panjer Denpasar Selatan memiliki tata cara tertentu dalam pementasannya yang bersifat turun temurun dari generasi ke generasi hingga saat ini masih tetap dilestarikan. Sehingga terciptalah keberlajutan yang diyakini sebagai tata aturan yang bersifat mengikat atau baku dari proses hingga pementasan tari selesai. Informasi dari berbagai sumber kajian mengenai awal mula keberadaan tari Telek, tidak dapat dipastikan kapan dan siapa yang menciptakannya. Tari tradisi Telek ini merupakan ungkapan pengalaman hidup dan 
emosi bersama masyarakat penyangganya. Tarian yang merupakan warisan leluhur tanpa identitas pemilik biasanya dikatakan bersifat anonim. Berdasarkan dari hasil observasi, Tari Telek di Banjar Kangin Desa Adat Panjer dipercaya sudah mengalami perjalanan sejarah yang cukup lama, hingga tidak diketahui awal keberadaannya di Banjar Kangin Desa Adat Panjer. Walapun bersifat anonim tari Telek ini masih tetap dilestarikan dengan selalu bertumpu pada pola tradisi dari masyarakat penyangganya. Berdasarkan bentuk penyajiannya tari Telek ini dapat dikategorikan dalam bentuk tari kelompok yang dibawakan oleh sembilan orang penari, diantaranya yaitu: empat orang penari wanita dengan ciri khasnya menggunakan topeng berwarna putih yang biasa disebut Telek luh. Dua orang penari laki-laki yang secara umum disebut Jauk manis atau Telek muani dengan menggunakan topeng berwarna putih berparas laki-laki dengan karakter halus. Dua orang penari laki-laki yang secara umum disebut Jauk keras dengan menggunakan topeng berwarna merah sebagai penggambaran karakter keras. Istilah Jauk keras di Banjar Kangin menggunakan istilah yang berbeda, yaitu Penamprat dan Sobrat. Kemudian satu orang penari laki-laki sebagai Ratu dengan ciri khas seperti Jauk keras, akan tetapi menggunakan gigi jongor atau gigi yang maju ke depan dan menggunakan hiasan kepala gelungan candi kurung. Seni tari sebagai ekspresi manusia yang bersifat estetis, kehadirannya secara tekstual dapat dilihat dari bentuk koreografinya (Sumandiyo Hadi 2005: 13). Koreografi atau yang bisa disebut sebuah penulisan tarian kelompok dapat digunakan untuk membahas unsur-unsur yang membentuk sebuah karya tari. Berdasarkan dari bentuk koreografinya, tari Telek yang ada di Banjar Kangin Desa Adat Panjer Denpasar Selatan tersebut termasukjenis tari drama. Karena pementasan tari Telek dan Jauk tersebut menjadi satu kesatuan yang utuh dalam pertunjukan atau sesolahan dari Sesuhunan Barong, Rangda, Rarung dan Topeng Sidakarya yang menyajikan unsur drama. Pertunjukan tari Telek yang menjadi bagian dalam pementasan dari Sesuhunan tersebut, menampilkan sajian pertunjukan yang bersifat naratif, menggunakan gerak dan vocal dalam sajiannya, sehingga pertunjukan tari Telek ini secara keseluruhan dapat disebut dengan dramatari.

Bentuk tari dalam perwujudannya adalah sesuatu yang dapat dinikmati oleh indera. Bentuk yang dimaksud, yaitu visualisasi fisik dari tubuh penari hingga kelengkapan dan penunjang dalam

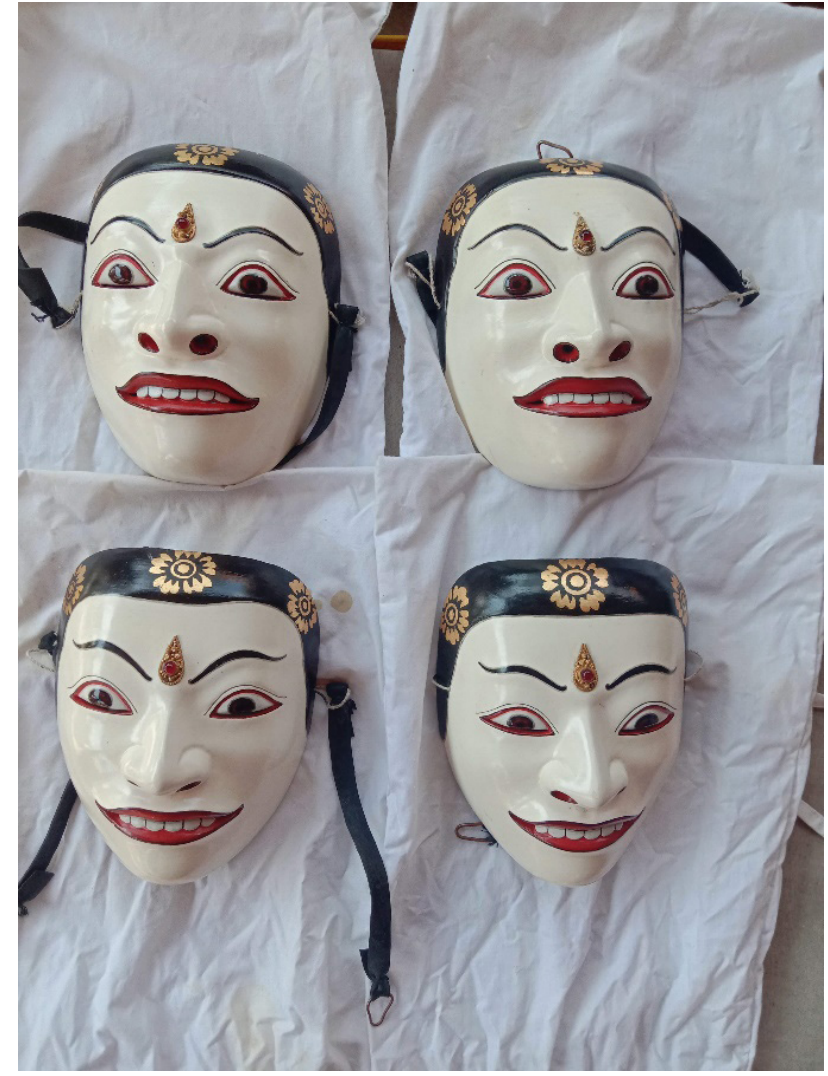

Gambar 1. Topeng Tari Telek di Banjar Kangin Desa Adat Panjer.

(Sumber: Dokumentasi Ni Made Liza Anggara Dewi 2021)

pementasan tari di atas panggung. Secara fisikal yang dapat ditangkap oleh indera dalam pertunjukan tari Telek antara lain: struktur dan gerak tari, penari, musik pengiring, kostum tari, panggung, tata cahaya, dan properti. Struktur tari merupakan pola bangun dari susunan unsur koreografi yang terangkai sedemikian rupa. Tari Telek yang ada di Banjar Kangin Desa Adat Panjer memiliki struktur pertunjukan, sebagai berikut: Pepeson atau bagian awal penari baru keluar, pengawak atau bagian isi dengan gerak dan tempo yang lebih lambat, pengecet atau bagian akhir dari tarian, dan pekaad atau bagian ketika penari masuk ke dalam atau keluar dari panggung yang menandakan pertunjukan telah berakhir. Tari Telek yang ada di Banjar Kangin Desa Adat Panjer merupakan bagian dari pertunjukan dari Sesuhunan berupa Barong, Rangda, Rarung, dan Topeng Sidakarya. Struktur tari Telek secara keseluruhan dapat dijabarkan sebagai berikut, yaitu: 1) Pada bagian awal pertunjukan, disajikan tari Telek sebagai tari pembuka yang dibawakan oleh empat orang penari putri yang biasa disebut luh-luh Telek. 2) Keluar dua orang penari Jauk manis, yang diikuti oleh dua Jauk keras diantaranya adalah satu orang Sobrat dan satu orang Penamprat, dan terakhir satu 
orang Jauk keras sebagai Ratu. 3) Ada interaksi antara tari Telek dan tari Jauk tersebut, kemudian terjadi komplik sehingga penari Telek melakukan gerakan seperti mengusir penari Jauk. 4) Penari Telek keluar/masuk ke dalam yang menandakan bagian awal pembuka tari Telek dan Jauk selesai. 5) Dilanjutkan dengan tari Barong, dan beberapa saat kemudian Barong digoda oleh penari sobrat/ penamprat. 6) Sesuhunan Barong diistirahatkan, dengan posisi masih di atas panggung, yaitu tepatnya bagian depan panggung dengan menghadap ke belakang atau ke panggung. 7) Penari Telek menari sebentar, kemudian mengambil posisi yang sama, berada di depan panggung menghadap ke belakang, dengan melakukan gerakan ngepik atas. 8) Penari Jauk menari sebentar kemudian melakukan interaksi dengan penari Telek dan keluar/masuk ke dalam. 9) Dilanjutkan dengan tari Rarung dan melakukan adegan persemedian. 10) Tari Barong mulai menari kembali dan menggangu pertapaan atau persemedian Sesuhunan Rarung. 11) Sehingga terjadi pertarungan antara Sesuhunan Rarung dengan Sesuhunan Barong dan pihak Sesuhunan Rarung mengalami kekalahan. 12) Karena Sesuhunan Rarung kalah dan merasa dirinya benar, kemudian Sesuhunan Rarung meminta pertolongan kepada Sesuhunan Rangda. 13) Sesuhunan Rangda menari dan Sesuhunan Rarung keluar/masuk ke dalam. 14) Sehingga pertarungan antara Sesuhunan Rangda dan Sesuhunan Barong pun terjadi, yang mengakibatkan Sesuhunan Barong takut dan mengalah pergi keluar/masuk ke dalam. 15) Bagian akhir yaitu Sesuhunan Rangda diserang dari berbagai arah. Karena setiap sesolahan atau pertunjukan tari dari Sesuhunan ini dipentaskan, dipercaya energi dari kekuatan Sesuhunan Rangda yang begitu kuat membuat masyarakat sekitar kerasukan dan menyerang Sesuhunan Rangda dengan membawa senjata keris sambil ngunying. Biasanya orang yang mengalami kerasukan tersebut menyebutkan bahwa dirinya dirasuki oleh siapa yang ingin menyerang dan mengalahkan kekuatan Sesuhunan Rangda. 16) Pada akhirnya semua yang ingin menyerang Sesuhunan tersebut kalah dan pertunjukan berakhir yang ditandai dengan masuknya Sesuhunan Rangda ke dalam atau keluar dari pangung pementasan. Khusus sajian pertunjukan Sesuhunan yang menampilkan Sesuhunan Topeng Sidakarya biasanya dilakukan pada waktu tertentu saja.

Tari Telek yang ada di Banjar Kangin Desa Adat Panjer Denpasar Selatan ini memiliki pola gerak tari yang berbeda dari tari Telek pada umumnya. Adapun ciri khas yang utama dari tari Telek ini adalah sebagai berikut: 1. Gerakan nyregseg pada umumnya dilakukan dengan posisi kaki tumit diangkat dan bertumpu pada gajul yang digerakan kecil-kecil ke kanan dan ke kiri. Tari Telek yang ada di Banjar Kangin menggunakan gerakan nyregseg, yang dilakukan dengan langkah kaki ke kanan dan ke kiri masing-masing empat kali dengan teknik dihentak-hentakan. 2. Gerakan bagian kupu-kupu tarum yaitu gerakan antara dua penari Telek yang saling keterkaitan satu sama lain. Gerakan tersebut dilakukan berbeda antara penari satu dengan langkah kaki empat kali ke kanan dan dalam waktu yang bersaman penari kedua melangkah empat kali ke kiri, kemudian pada hitungan ke empat fokus pandangan saling berhadapan. Gerakan kupukupu tarum ini bisa dilakukan dengan berhadaphadapan dan posisi depan belakang. Tari Telek yang ada di Banjar Kangin Desa Adat Panjer tersebut secara keseluruhan pementasan dibawakan oleh 13 orang penari, diantaranya adalah empat orang penari Telek, dua orang penari Jauk manis, dua orang penari Sobrat/Penamprat, satu orang penari Ratu, satu orang penari Barong, satu orang penari Rarung, satu orang penari Rangda, dan satu orang penari Topeng Sidakarya. Semua penari diharuskan dari masyarakat Banjar Kangin Desa Adat Panjer Denpasar Selatan dan tidak boleh ditarikan oleh masyarakat lain dari luar. Pemilihan penari dilakukan oleh panitia seka Barong tersebut dengan melihat kemampuan menari atau yang memiliki teknik dasar tari dari calon penari tersebut atau orang yang dianggap mampu untuk membawakan tarian Telek dengan baik. Semua penari Telek yang dipilih dilatih dan diupacarai atau disucikan yang disebut dengan upacara mawinten. Kemudian baru diperbolehkan mementaskan tari Telek tersebut dalam konteks upacara agama sesuai dengan tradisi desa setempat. Kegiatan latihan untuk para penari dijadwalkan, ketika dirasa akan membutuhkan generasi baru sebagai pengganti. Diawali dari sebagai penari cadangan, yang hanya bisa ngayah menari ketika penari utama berhalangan atau mengalami cuntaka. Dikemudian hari akan menjadi penari utama dan terus berlanjut ke setiap regenerasi berikutnya.

Setiap enam bulan sekali, yaitu pada Rerahinan Tumpek Landep bertepatan dengan upacara Sesuhunan semua penari melakukan upacara penyucian agar mendapatkan penyegaran kekuatan atau taksu. Sehingga sehari setelahnya ketika 
pementasan pertunjukan tari dilaksanakan, semua penari dapat menyatu sepenuhnya dengan sosok Sesuhunan atau topeng yang disakralkan tersebut. Semua penari melaksanakan kewajibannya dengan sistem ngayah, dengan rasa pengabdian yang tulus, dan keyakinan yang begitu kuat dari seluruh masyarakat Banjar Kangin Desa Adat Panjer terhadap keberadaanNya. Secara tradisional, bentuk tari tidak terpisahkan dari sebuah musik pengiringnya. Keduanya bersumber dari dorongan atau naluri ritmis manusia. Wujud ritme tari dapat dilihat dari geraknya dan wujud musik dapat dilihat dari tatanan bunyi atau suara, kemudian musik dalam hubungannya dengan tari adalah sebagai ritme dan tempo, pencipta suasana, gaya dan bentuk, serta sebagai inspirasi (Murgianto, 1986:31). Tari Telek yang ada di Banjar Kangin ini menggunakan instrumen gamelan palegongan dengan konsep klasik pola kekuntiran. Serta ciri khas yang paling utama dalam instrusmennya adalah menggunakan gong khusus yang hanya digunakan dalam mengiringi Sesuhunan saja. Memiliki suara gong yang khas dan juga disakralkan. Penabuh atau pemain musiknya merupakan warga masyarakat Banjar Kangin dan juga harus melalui proses pawintenan atau penyucian sebelum menjadi pengayah dalam sesolahan Sesuhunan tersebut. Adapun instrumen yang digunakan antara lain: dua buah gender rambat, dua buah kendang, sepasang kendang krumpungan, sepasang kendang bebarongan, dua buah gender kantil, empat buah gangsa jongkok, empat buah gangsa biasa, empat buah kantil, dua buah kantil, dua buahjegog, dua buah jublag, gong bebarungan, satu buah klemong, satu buah klenang, satu buah kajar trenteng, satu buah kecek, dan suling.

Tata busana tari Telek yang ada di Banjar Kangin, awalnya sangat sederhana yaitu menggunakan topeng sakral yang masih awet sampai saat ini tersebut, baju panjang berwarna putih, celana panjang berwarna putih, simping kain berwarna poleng, selendang warna-warni, lamak, gelungan dan properti kipas. Akan tetapi perkembangannya saat ini sudah mengikuti tata busana tari Telek pada umumnya yaitu menggunakan topeng, baju lengan panjang berwarna putih , celana panjang berwarna putih, semayut, keris, awiran, awir bawah, lamak, angkep pala, badong, gelang kana, kamen, stewel, gelungan dan properti kipas. Karena tata busana yang digunakan cukup banyak dan berat membuat penari cepat lelah. Sehingga ada beberapa bagian pertunjukan yang dirubah untuk efisiensi waktu khususnya untuk para penari Telek. Tempat pementasan tari Telek tersebut dilakukan di kalangan jabe sisi baik itu di Pura Dalem Desa Adat Panjer, di Pura Dalem Tanjung Sari, Desa Adat Tanjung Bungkak, maupun di Pura Tegal Penangsaran, di mana tari Telek biasa dipentaskan. Sebelum pementasan, tempat pementasan tersebut dibersihkan terlebih dahulu baik secara sekala dan niskala. Tempat pementasan diupacarai atau disucikan terlebih dahulu, baru kemudian dirias diberikan hiasan panggung seperti bantrangan yg dipasang kanan-kiri depan panggung dan kober sebagai simbol gunung pada bagian belakang panggung. Pementasan sesolahan Sesuhunan yang menampilkan tari Telek di dalamnya tersebut merupakan pertunjukan tradiosional yang rutin dipentaskan. Sehingga sajian pertunjukannya tidak menggunakan teknik tata cahaya yang khusus. Pementasan tari Telek tersebut menggunakan tata cahaya general. Serta sebagai pelengkap utama lainnya, yang tidak boleh dilupakan adalah setiap pementasan dilakukan, wajib menghaturkan serangkaian sesaji untuk melengkapi ritual dalam pertunjukan tari Telek yang merupakan bagian dari pementasan Sesuhunan tersebut. Sehingga bagi masyarakat yang hendak menghaturkan sesolahan atau pertunjukan tari dari Sesuhunan wajib menyediakan serangkaian sarana upacara tersebut.

\section{Fungsi Tari Telek di Banjar Kangin Desa Adat Panjer Denpasar Selatan}

Fungsi tari Telek yang ada di Banjar Kangin jika dikaitkan dengan keberadaannya dalam masyarakat, yaitu tidak hanya sekedar sebagai aktifitas kreatif dari pelaku seninya. Fungsi utama tari Telek tersebut lebih mengarah pada kegunaannya dalam kehidupan masyarakat, khususnya Banjar Kangin Desa Adat Panjer Denpasar Selatan. Menurut (Bandem pada Hidayat, 2009: 40) Tari Bali dibedakan menjadi Sakral dan Profan, sakral dalam hal ini kehadirannya memiliki kaitan dengan pelengkap upacara tertentu. Tari Telek yang merupakan bagian dari pementasan Sesuhunan Desa Adat Panjer tersebut memiliki nilai guna dan hasil guna yang memberikan manfaat pada masyarakat. Fungsi utama tari Telek yang ada di Banjar Kangin Desa Adat Panjer Denpasar Selatan ini merupakan sebagai pengiring tari dari pementasan Sesuhunan Barong, Rangda, Rarung dan Topeng Sidakarya yang tidak dapat berdiri sendiri dan dipisahkan satu sama lain. Kehadiran tari Telek yang merupakan bagian dalam pementasan dari Sesuhunan tersebut merupakan sebagai sarana pengungkapan kepercayaan atau keyakinan dari 




Gambar 2. Sesuhunan Ratu Rangda, Topeng Sidakarya, dan Rarung di Desa Adat Panjer. (Sumber Dokumentasi Ni Made Liza Anggara Dewi 2021)

masyarakat penyangganya. Keyakinan masyarakat atas semua perlindungan tersebut, bersumber dari kekuatan Sesuhunan yang dianggap berkuasa atas bagian tertentu dari alam semesta. Menurut William Havilland dalam Saebani (2019:244) kepercayaan terhadap mahluk dan kekuatan supernatural yang dianggap dapat mengendalikan alam semesta, terkait dengan usaha manusia yang tidak dapat mengendalikan permasalahannya dengan cara biasa, kemudian berpaling melalui upacara dan persembahan, memohon pertolongan dan perlindungan kepada Tuhan, dan diyakini semua kekuatan bersumber dariNya.

Keyakinan masyarakat Banjar Kangin yang begitu kuat terhadap keberadaan Sesuhunan sebagai simbol manifestasi Tuhan yang menjaga dan melindungi masyarakat Banjar Kangin, yaitu berupa Barong, Rangda, Rarung, dan Topeng Sidakarya. Pertunjukan tari Telek yang merupakan bagian dari pementasan Sesuhunan tersebut merupakan salah satu cara pengungkapan keyakinan masyarakat penyangganya terhadap keberadaan Tuhan yang menjadi kekuatan dan pelindung bagi umatnya. Sehingga pementasan tari ini berfungsi sebagai sarana kegiatan ritual yang hingga kini masih dipentaskan di tiga tempat, yaitu 1) di Pura Dalem Desa Adat Panjer dimana tempat berstananya Sesuhunan, dan upacaranya pada hari Rahinan Tumpek Krulut, kemudian sehari setelahnya akan dilaksanakan pementasan tarinya. 2) di Pura Dalem Tanjung Sari Desa Adat Tanjung Bungkak tempat dimana asal usul bahan kayu dari topeng Sesuhunan Barong dan Rangda pergantian kedua, dan upacaranya pada hari
Rahinan Anggara Kasih Medangsia, dan 3) di Pura Tegal Penangsaran Desa Adat Panjer tempat asal kayu bahan dari topeng Rangda pergantian pertama, dan upacaranya pada hari Rahinan Tumpek Krulut. Menurut (Piliang dalam Nuriarta 2019: 119) dua tingkatan pertandaan (staggered system), yang memungkinkan dihasilkannya makna yang juga bertingkat, begitu pula bagaimana masyarakat memaknai tari Telek ini sudah sampai ke sistem pemaknaan tingkat kedua, yang memungkinkan fungsi ini berkaitan dengan sistem mitos yang terjadi di masyarakat Banjar Kangin. Pementasan pertunjukan tari ini dilakukan selain sebagai sarana ritual dalam upacara agama di tiga tempat tersebut, juga merupakan sebagai sarana pembayaran janji atau hutang dari masyarakat yang membutuhkan pertolongan atau anugrah dari kekuatan Sesuhunan tersebut. Kepercayaan masyarakat Banjar Kangin terhadap Sesuhunannya, yaitu seperti ketika ada orang yang menderita sakit parah dan sudah tidak ada obat yang bisa menyembuhkannya, biasanya kepercayaan masyarakat Banjar Kangin, yaitu orang yang menderita sakit atau dari anggota keluarganya tersebut akan melakukan doa berupa janji dengan sarana persembahan kehadapan Sesuhunan yang dipercayai untuk dapat diberikan kesehatan atau kesembuhan, serta berjanji akan menghaturkan pertunjukan tari jika sembuh nanti. Kepercayaan masyarakat Banjar Kangin terhadap Sesuhunannya setara dengan kepercayaan masyarakat terhadap agama yang dianutnya. Seperti yang dikatakan Budi Susanto dalam bukunya Kebudayaan dan Agama mengatakan bahwa agama merupakan sebuah simbol sakral yang menghubungkan sebuah ontology dan kosmologi dengan sebuah moralitas 1992:51).

Kepercayaan masyarakat setempat dari tahun 1958 ketika awal mula sesuhunan dibangkitkan kembali setelah pandemi cacar tersebut hingga sekarang, keyakinan masyarakat sangat kuat terhadap kekuatan dan keberadaan sesuhunan yang selalu melindungi masyarakatnya dari bencana dan mara bahaya. Sehingga terbentuk sebuah sistem kepercayaan yang bersifat religius dari serangkaian simbol sakral yang terjalin menjadi sebuah keseluruhan yang teratur. Selain menjadi sebuah sarana ritual keagamaan dan kepercayaan masyarakat penyangganya Tari Telek yang ada di Banjar Kangin Desa Adat Panjer juga dapat dilihat dari persfektif estetikanya. Fungsi tari dalam sebuah karya seni, dari perspektif estetika yaitu dapat dilihat dari pengalaman estetis pelaku dan penikmat seninya (Deni Junaedi 2016:189). 
Tari Telek di Banjar Kangin juga merupakan sebagai sarana hiburan pribadi bagi pelaku dan penikmat seni tersebut dan juga sebagai presentasi estetis, dimana pertunjukan tersebut ditata secara khusus untuk dipertunjukan atau dipertontonkan di atas panggung untuk disajikan pada penikmatnya yaitu masyarakat setempat sebagai penonton dimana pertunjukan tari tersebut dipentaskan.

\section{SIMPULAN DAN SARAN}

Berdasarkan Uraian diatas adapun simpulan yang dapat ditarik, adalah tari Telek yang ada di Banjar Kangin Desa Adat Panjer Denpasar Selatan ini merupakan bagian dari masyarakat itu sendiri yang tidak bisa lepas dari keberadaan, khususnya dalam hal ini sistem pekercayaan yang dianut masyarakat sekitarnya. Pada dasarnya tari Telek ini merupakan suatu pengiring pertunjukan untuk tari Barong, Rangda, Rarung, dan juga Topeng Sidakarya yang merupakan sarana pelengkap upacara agama di Banjar Kangin Desa Adat Panjer. Secara keseluruhan bentuk tari Telek ini bersifat naratif, menggunakan gerak dan vocal sehingga pertunjukan tari Telek merupakan sajian pertunjukan dalam bentuk dramatari. Adapun fungsi dari tari Telek selain sebagai tari pelengkap upacara juga sebagai sarana pembayaran janji atau hutang dalam sistem Sesangi dari masyarakat yang membutuhkan sebuah anugerah pertolongan dari kekuatan supernatural yang diyakini masyarakat penyangganya terhadap Sesuhunan berupa Barong, Rangda, Rarung, dan Topeng Sidakarya sebagai simbol Tuhan kepercayaan masyarakatnya.

Adapun saran untuk pihak terkait yang terlibat dalam upaya penggalian seni tradisi langka, dapat mempertimbangkan tari Telek di Banjar Kangin Desa Adat Panjer sebagai sebuah warisan budaya yang mutlak harus dilestarikan dan diwariskan secara turun temurun dari generasi ke generasi berikutnya. Upaya seperti konservasi dan rekontruksi perlu dilakukan dengan memperhatikan nilai-nilai dasar yang menjadi ciri khas keberadaan tari Telek dengan bentuk dan gayanya tersendiri. Sebab seni tari merupakan seni multidisiplin yang merupakan sebuah produk dari suatu masyarakat, mengandung nilai yang dianut suatu masyarakat, berbedaa dari nilai yang dianut oleh masyarakat lain, sehingga perlu mengapresiasi tari dengan acuan nilai yang dianut masyarakat pemiliknya.

\section{DAFTAR RUJUKAN}

Bandem,I Made 1983. Ensiklopedi Tari Bali, Denpasar; Akademi Seni Tari Indonesia (ASTI)

Budihartini, Pan Putu. 2000. Rangda dan Barong Unsur Dualistik. Denpasar

Cerita, I Nyoman 2020. Teks Dan Konteks Di Balik Seni Pertunjukan Bali. Denpasar: Japa (Pt. Japa Widya Duta)

Dibia, I Wayan. 1999. Selayang Pandang Seni Pertunjukan Bali. Masyarakat Seni Pertunjukan Indonesia. Bandung

Hadi, Sumandiyo 2005. Sosiologi Tari Sebuah Pengenal Awal. Pustaka. Yogyakarta

Hidayat, Robby 2009 Pengetahuan Seni Tari, Malang: Jurusan Seni dan Desaib fakultas sastra Universitas Negeri Malang.

Junaedi, Deni 2016. Estetika Jalinan Subjek Objek dan Nilai. ArtCiv. Yogyakarta

Murgiyanto, Sal, 1986. Komposisi tari, Jakarta: Direktorat jendral Pengembangan Kesenian.

Nuriarta, I. W., \& Wirawan, I. G. N. (2019). Kajian Komik Kartun Panji Koming Di Tahun Politik. Segara Widya : Jurnal Penelitian Seni.

Kuta ratna, Nyoman, 2010. Metodelogi Penelitian Kajian Budaya da Ilmu Sosial Humaniora pada Umumnya, Yogyakarta: Pustaka Pelajar.

Saebani, Beni Ahmad, 2019 Pengantar Antropologi, Bandung: Pustaka Setia

Sugiyono, 2019. Metode Penelitian Pendidikan. Bandung: Alfabeta

Sedyawati, Edi, dkk. 1986. Pengetahuan Elementer Tari Dan Beberapa masalah Tari. Direktorat Kesenian Proyek Pengembangan Kesenian Jakarta Departemen Pendidikan dan Kebudayaan. Jakarta

Susanto, Budi, 1992. Kebudayaan dan Agama. Kanisius. Yogyakarta 